\title{
The Perfect Communication Storm: News Coverage of the Patient Protection Affordable Care Act
}

\author{
Tucker-McLaughlin Mary, Jin-Ae Kang \\ School of Communication, East Carolina University, Greenville, NC, USA \\ Email: tuckermclaughlinm@ecu.edu
}

How to cite this paper: Mary, T.-M., \& Kang, J.-A. (2019). The Perfect Communication Storm: News Coverage of the Patient Protection Affordable Care Act. Open Journal of Political Science, 9, 299-313. https://doi.org/10.4236/ojps.2019.92017

Received: January 8, 2019

Accepted: March 11, 2019

Published: March 14, 2019

Copyright ( 2019 by author(s) and Scientific Research Publishing Inc. This work is licensed under the Creative Commons Attribution International License (CC BY 4.0).

http://creativecommons.org/licenses/by/4.0/

\section{(c) (i) Open Access}

\begin{abstract}
This study contributes a historical perspective to communication that surrounds health care policy. The importance of the role of media in the establishment of public policy is highlighted, as well as an administration's ability to educate the media and public about proposed legislation. Using content analysis, the researchers examined how White House news releases and television news stories represented the Patient Protection and Affordable Care Act (PPACA) from its initial discussion in January 2009 through March of 2012. The results showed neither the White House news releases, nor the network television news stories provided the public with a comprehensive outline of the PPACA. Both the Obama administration and the media presented the PPACA as an important current issue, but both failed to define it in ways that made the legislation accessible to the public. The lack of definitive information created confusion for the public and this health care policy remains a controversial piece of legislation which has been threatened with repeal.
\end{abstract}

\section{Keywords}

Health Care, Reform, Obama, PPACA, Framing Television News, News Releases

\section{Introduction}

Affordable health care has been a dominant theme in American politics since the 1992 Clinton administration. In 2013 health care spending occupied more than one sixth of the US economy (Kane, 2012). According to the Centers for Disease Control, over 45 million Americans under the age of 65 were uninsured in 2011, 
prior to the enactment of the PPAC (CDC, 2012). The Obama administration initiated health care reform in 2009, ultimately passing the Patient Protection and Affordable Care Act (PPACA) in 2010 and implementing it in 2012 (White House, 2012).

When legislation as monumental as the PPACA enters the media spotlight, it raises questions about the role that media content plays in the comprehension of the legislation by the public. Using content analysis, White House new releases and television news stories representing the PPACA are compared. The data set included releases and news stories from January 2009 through March of 2012.

By comparing the information distributed in White House news communications and the television news stories which ran concurrently, the researchers determined that the Obama administration played a pivotal role in the inability of the media to provide comprehensive information about the PPACA to the public. While the frames used by the media contributed to a lack of comprehensive information of the legislation, the analysis determined that because of White House public relations strategies, the journalists lacked access to information that would have helped them to better inform viewers.

\subsection{Network News and Heuristics}

Although Internet and cable news programs continue to gain audience members, Americans continue to rely on network television newscasts as an important source of information with audience percentages increasing by one percent for network news in 2015 (Morris \& Forgette, 2007; Sonderman, 2012). These network news programs serve an important function by providing a summary of current events and critical issues. Specifically, the public continues to rely on network television news coverage for knowledge and comprehension on issues in healthcare (Dan, 1992; Dorfman, Halpin Schauffler, Wilkerson, \& Feinson, 1996; Morris \& Forgette, 2007; Purcell, Rainie, Mitchell, Rosenstiel, \& Olmstead, 2010; Sonderman, 2012). This brings the importance of network news coverage and news releases to the forefront.

Most individuals base important decisions on heuristics, or short-cuts to judgment and decision making. Previous research suggests that when individuals have limited access to resources upon which to base these decisions, the decisions are susceptible to the way issues are framed in available resources, specifically media coverage (Peters, McCaul, Stefanek, \& Nelson, 2006; Slovic, 1995; Entman, 1993). Since television provides an easily accessible heuristic for individuals seeking knowledge about what is going on around them (Wallack \& Dorfman, 1992), the way journalists frame these issues affects the audience's comprehension, perception, and acceptance of them (Culbert, 1998; Edy, 1999; Ha-Ilan, 2001; Hallin, 1984; Tuchman, 1978). Behavioral science and mass communications scholars suggest that the viewing audience uses news frames as a way of understanding important issues, like the PPACA (Entman, 1993; Gitlin, 1980; Rhode, 1995; Tuchman, 1978; Tuchman, 1979; Wallack \& Dorfman, 1992). 


\subsection{Journalism Routines and Practices}

Journalists routinely frame news stories from a specific perspective, choosing one angle to narrow the story. Entman defines framing as the determination of selection and salience (Entman, 1993). Using framing, an individual selects some meaningful point of reference in a perceived reality and makes it more salient. In terms of journalism, the journalist chooses a frame for a story in order to present a topic more efficiently: covering one part of the topic, but not its entirety. Entman (1993) emphasizes that this framing is a causal interpretation, or a treatment recommendation which at times presents a moral evaluation of a subject. This causal interpretation is particularly pertinent to health communication as for many the news media are their sole resource for health information (Dutta-Bergman, 2004).

Frames in any given news story instruct the audience on how to think about issues (Culbert, 1998; Curkan-Flanagan, 2000; Dutta-Burgman, 2005; Farnsworth \& Lichter, 2011; Terkildsen \& Schnell, 1997). As television journalists prepare stories for the evening newscast, they often make a conscious decision to cover a story using a particular frame. While the PPACA news-of-the-day may involve five different topics, the journalist decides on only one or two of these topics to frame the entire story. Framing in television news prompts the audience to think about an issue by presenting some frames, while ignoring others (Entman, 1993). Human impact, economics, and conflict are common frames in news stories. The most prevalent of these frames is conflict (Claes, 2012). It is clear that the media contribute to our understanding of issues (Claes, 2012; Gamson \& Modigliani, 1989; Scheufele, 1999). Some scholars argue that the contribution of media frames to public discourse on issues is strong (McQuail, 2005).

Story frames are also affected by the language journalists use to describe an issue (Entman, 1993; Gamson \& Modigliani, 1989; Gans, 1980). When emotive language is used, it presents an issue or person to the audience in a particular way (Rodman \& Adler, 2002). If journalists present legislators as battling over an issue, the audience is given a different picture than if journalists report that legislators are discussing an issue. Language is critical to the frame of a story and lends salience to what the reporter is saying (Entman, 1993).

Sound bites are an integral part of television news stories. The average sound bite in 1968 of 45 seconds diminished to an average of 10 seconds by 1988, and further dwindled to an average of seven to eight seconds by 1992 (Farnsworth \& Lichter, 2011; Lichter \& Noyes, 1995). The reduced time availability in network news production results in presentation of news through a simplified lens rather than comprehensive presentation of issues (Farnsworth \& Lichter, 2004; Farnsworth \& Lichter, 2011). This more simplified lens which arises from time constraints, may have also contributed to the way in which network media presented the PPACA to the viewing public.

Journalists get sound bites by interviewing sources. Comprehensive news coverage is only possible through reliable and informative news sources. A story 
without sources to confirm or deny information, will not air (Gans, 1980; Hansen \& Ward, 1994). With the PPACA, the only available source was the White House. Like other information sources, the White House relied on the White House correspondents and other journalists to carry their message about the PPACA to the public. The White House likely did not anticipate that journalists would relay their messages verbatim. However, the White House framed the PPACA information in the hopes that journalists would use similar frames to publicize the message. The chronology of the flow of information also may have impacted the frames adopted by the journalists. The rough draft of the PPACA was released over nine months after the PPACA was announced by the White House (Cortes, 2009). With no draft of legislation to refer to, journalists relied upon the White House for the PPACA details.

In this study, we examine how the PPACA was framed by the White House through news releases (RQ1). We then examine how journalists framed the PPACA in the news stories (RQ2). Looking at both sets of data, we compare the media messages in the news releases issued by the White House to the network news coverage presented by three specific media outlets (RQ3). Through this comparison, we sought to determine if comprehensive information was provided to allow for complete coverage of this important new health care legislation by addressing the following research questions:

RQ1: What were the predominant representations of the PPACA in White House news releases between January 2009 and March 2012?

RQ2: What were the predominant representations of the PPACA in network news stories between January 2009 and March 2012?

RQ3: To what extent do representations in the network news stories reflect representations provided by the White House news releases?

\section{Methods}

\subsection{Sample}

Content analysis was conducted on a representative sample of White House news releases and network news stories. The first criterion for inclusion in the data set was that the content focused on the PPACA and the legislative process surrounding the health care bill. The second criterion for inclusion was the date the information was released, or broadcast to the public. The date parameters for both news releases and network news coverage extended from January 2009 through March 2012. These dates followed the White House's proposed calendar of healthcare reform actions (Table 1), a timeline which indicated the White House's communication intentions for the PPACA.

News releases were obtained from the White House website. A total of 13 releases issued by the White House between January 2009 and March 2012 carried information that pertained to the PPACA. Network news stories were obtained from the Vanderbilt Television News Archives through grant money provided by a Southeastern university. The three networks whose news stories were 
Table 1. White House timeline of Patient Protection and Affordable Care Act (PPACA) through March 2012.

\begin{tabular}{|c|c|}
\hline $02 / 24 / 2009$ & President Obama Promises Health Care Reform in His first Address to a Joint Session of Congress \\
\hline 03/05/2009 & The White House Summit on Reforming Health Care \\
\hline 09/09/2009 & President Obama Lays Out His Vision for Health Care Reform during an Address to a Joint Session of Congress \\
\hline $01 / 27 / 2010$ & In First State of the Union, President Obama Focuses on Health Care Reform \\
\hline $02 / 25 / 2010$ & A Bipartisan Summit on Reform at the White House Leads to an Open, Honest, and Productive Discussion \\
\hline $03 / 23 / 2010$ & President Obama Signs the Affordable Care Act, an Historic Overhaul of the American Health Care System \\
\hline $06 / 10 / 2010$ & Seniors See the First Benefit of the Affordable Care Act as $\$ 250$ Rebate Checks Are Sent \\
\hline 07/01/2010 & Now Uninsured Americans with Pre-Existing Conditions Have Access to Coverage \\
\hline $09 / 23 / 2010$ & Patients Can Now Take Advantage of Their First New Set of Protections \\
\hline 01/01/2011 & Free Preventive Care for Seniors \\
\hline 09/01/2011 & Lowering Costs for American Consumers \\
\hline $12 / 14 / 2011$ & $\begin{array}{l}\text { The Results Are In. Since the new law came into effect in September 2010, } 2.5 \text { million more Americans } \\
\text { under the age of } 26 \text { have received coverage by registering under their parents' health insurance plans. }\end{array}$ \\
\hline $02 / 28 / 2012$ & Protecting Taxpayer's Money \\
\hline
\end{tabular}

Note: Source: https://obamawhitehouse.archives.gov/briefing-room.

included in the data set included ABC, CBS, and NBC. These networks were selected for two reasons: 1) all three have evening newscasts, and; 2) these networks are available to the public without subscription to cable services, thereby potentially reaching the largest available audience (Berry, 2009).

A few other criteria limited the sample news stories issued by the three networks during the selected time frame. First, special programs, such as ABC's Nightline were not included as they do not attract the same audiences as the network evening newscast and differ in programming lengths and air times. "State of the Union" addresses were also not included due to limited substantial coverage of PPACA within the addresses. The data set included 73 network news stories, totaling approximately five hours of news coverage. Stories were gathered using an exhaustive search based on the dates of the timeline and the key words "Health care and Obama". The stories analyzed here include all stories broadcast on those dates including at times, a day before and after those dates. Forty-two of the news stories were aired on NBC (56.8\%), 28 on CBS (39.2\%), and 2 on $A B C(4 \%)$. The researchers hypothesize that few news stories were carried by $A B C$ because this network relied primarily on its special news magazine "Nightline" to discuss the Affordable Care Act. "Nightline" episodes were not included in the data set due to differences in audience makeup and the inherent differences between the news magazine format and the evening news formats. The fact that $\mathrm{ABC}$ broadcast so little coverage of the PPACA during the time period is meaningful as it offers a means of comparison with the other two major networks.

\subsection{Measures}

The units of analysis for the purposes of this study were the messages found in 
news releases and TV news segments. The news releases were defined by the terms used by the White House to describe their communication with journalists. The terms news release, briefing, and statement were used interchangeably by the White House in reference to this communication and all such applicable communications were then defined by this study as news releases.

A news segment was defined as either a stand-alone news story that consisted of a news package and a live shot (when appropriate), or an entire segment devoted to the topic of health care reform. Some segments contained multiple news packages presented by different reporters making up what the networks refer to as "team" coverage of a topic. A television news package is defined as a pre-produced story introduced by a television news anchor containing interviews and a voice track by the reporter, ending with an out cue (Tuggle, Carr, \& Huffman, 2007). Standard news packages are between one minute and a half to two minutes in length (Tuggle et al., 2007).

\subsection{Coding Categories}

A two-step process was used to develop the coding categories for content analysis. A previously validated coding framework that analyzed the Health Security Act (Dorfman et al., 1996) formed the foundation for the coding categories. Four categories defined by Dorfman et al. (1996) included financing, organization, eligibility and administration. Using these categories from earlier research as a starting point, a random number generator randomly selected 10 stories from the data set to serve as a pilot test of the coding scheme and applicability for the PPACA news releases and news stories. Three researchers coded the pilot sample to determine if these four categories (Dorfman et al., 1996) were comprehensive, that each was exclusive, and that each applied to the current research.

Upon review, the three researchers noted that the four categories were not comprehensive. A qualitative open coding process (Strauss \& Corbin, 1998: p. 101) allowed the researchers to analyze the selected portion of the data set and determine which categories formed a comprehensive, exclusive, and applicable coding scheme. This coding process was accompanied by a textual analysis of the language used by the White House and journalists to describe the PPACA. This language analysis was used to determine the tone of the stories. Each story was coded by three separate coders as being positive (representing the benefits of the PPACA), neutral, or negative (representing the risks of the PPACA). When the risks outweighed the benefits, the stories were coded as negative. Equal mention of both risks and benefits was given a neutral coding, and a story which presented the PPACA as having more benefits than risks was coded as positive.

Fifteen categories emerged from the pilot test analysis: 1) the government cost of PPACA, 2) PPACA premium \& cost in the current healthcare system, 3) taxes, 4) government option, 5) eligibility, 6) benefits, 7) prescription drugs, 8) preventative care, 9) penalties of not having health insurance, 10) Medicare, 11) Medicaid, 12) Congressional program, 13) Death Panel, 14) support of PPACA, and 15) Opposition to PPACA. The four categories utilized by Dorfman et al. 
(1996) were included in these 15 categories, with 11 others discovered to complete a more comprehensive coding scheme appropriate for PPACA analysis.

\subsection{Inter-Coder Reliability}

To check inter-coder reliability, the three researchers independently coded news stories and news releases. A random number generator again selected a sample from the data set of news releases and news stories. Six news releases $(46.2 \%$ of the total) and 16 news stories (21.9\% of the total sample) were analyzed. Analysis of inter-coder reliability (Cohen's Kappa) resulted in overall agreement between 0.808 and 1. Scott's $P$ i ranged from 0.735 to 0.786 . Since intercoder reliability rates were high, the researchers then coded the remaining data set with the 15 categories obtained through open coding.

\section{Results}

The main purpose of this study was to compare the content of White House news releases and network news stories for representation of the PPACA. Frequency analysis examined both the news releases and the network news stories to answer the first and second research questions. Research questions asked what the predominant representations of the PPACA were in White House new releases (RQ1) and stories broadcast by three news networks (RQ2) Subsequent analysis compared the two representations for variance. (RQ3). All data are presented in Table 2.

Table 2. Frequencies of news frames in network news and the White House News Releases.

\begin{tabular}{|c|c|c|c|}
\hline & Frames & $\begin{array}{l}\text { News Stories } \\
\quad(\mathrm{N}=73)\end{array}$ & $\begin{array}{c}\text { News Releases } \\
\quad(\mathrm{N}=13)\end{array}$ \\
\hline \multirow{3}{*}{ Financing } & The cost and/or budget of PPACA & $46.6 \%(34)$ & $46.2 \%(6)$ \\
\hline & $\operatorname{Tax}$ & $34.2 \%(25)$ & $7.7 \%(1)$ \\
\hline & $\begin{array}{l}\text { PPACA premium \& cost } \\
\text { in the current healthcare system }\end{array}$ & $21.9 \%(16)$ & $46.2 \%(6)$ \\
\hline \multirow{5}{*}{ PPACA contents } & Government Option & $45.2 \%(33)$ & $15.4 \%(2)$ \\
\hline & Eligibility & $31.5 \%(23)$ & $53.8 \%(7)$ \\
\hline & Benefits & $16.4 \%(12)$ & $23.1 \%(3)$ \\
\hline & $\begin{array}{l}\text { Penalties/ Requirement of } \\
\text { health insurance purchase }\end{array}$ & $12.3 \%(9)$ & $0 \%(0)$ \\
\hline & Prescription Drugs & $8.2 \%(6)$ & $30.8 \%(4)$ \\
\hline \multirow{4}{*}{$\begin{array}{l}\text { Current Government } \\
\text { healthcare programs }\end{array}$} & Preventative Care & $0 \%(0)$ & $23.1 \%(3)$ \\
\hline & Medicare & $19.2 \%(14)$ & $53.87(7)$ \\
\hline & Medicaid & $13.7 \%(10)$ & $30.8 \%(4)$ \\
\hline & Congressional & $27 \%(2)$ & $7.7 \%(1)$ \\
\hline Rumors & Death Panel & $12.3 \%(9)$ & $0 \%(0)$ \\
\hline Public and congressional & Opposition & $58.9 \%(43)$ & $7.7 \%(1)$ \\
\hline attitudes toward PPACA & Support & $49.3 \%(36)$ & $46.2 \%(6)$ \\
\hline
\end{tabular}

Note: Percentages do not add up to $100 \%$ because news segments could contain more than one topic frame. Percentages for topics within categories are percentages of the 73 total news and 13 news releases, respectively. 


\section{News Releases: RQ 1}

In RQ1, the two most frequent frames in the news releases were found to be Medicare $(53.9 \%, \mathrm{n}=7)$, and benefit eligibility $(53.8 \%, \mathrm{n}=7)$, followed by the cost of the PPACA $(46.2 \%, \mathrm{n}=6)$ and the cost of the current health care system $(46.2 \%, n=6)$. The news releases emphasized the demand of healthcare reform as urgent by pointing out the abundant cost of the current health care system. The White House also emphasized the philosophy of their reform as universal and affordable health care emphasizing the eligibility frame, and implying that the government could do the reform by enhancing Medicare efficiency (53.8\%, $\mathrm{n}=7)$, not by increasing the tax burden $(7.7 \%, \mathrm{n}=1)$.

While particular frames were emphasized by the White House, a story in September of 2009 reveals that the lack of information from the White House was strategized. This contributed to journalists' confusion and speculation. The CBS story on September 9, 2009, ran nearly 9 months after the introduction of the health care reform initiative. Then News Secretary David Axelrod stated in the interview that the Obama administration had strategized specifically to not initially roll-out a completed health care reform plan. Instead, they approached health care reform as an idea which needed to be formalized and asked for bipartisan input on the final product (Cortes, 2009). This approach, while gathering input and buy-in from various stakeholders, was strategically lacking in detail, thus creating a barrier to journalists' ability to accurately lay-out the plan in full. With no formal plan in place until well into the roll-out, the White House released little information on the PPACA. Within the over three-year time frame of the study, only 13 news releases were published by the White House concerning the PPACA. This sparse number of news releases had implications for journalists' ability to understand the PPACA and provide detail to the viewing audience.

\section{News Stories: RQ 2}

Four frames in the network news stories appeared more frequently. Those frames were opposition $(58.9 \%, \mathrm{n}=43)$ of the PPACA or support $(49.3 \%, \mathrm{n}=$ 36) from the public and congressional members, and cost of the proposed health care reform $(46.6 \%, \mathrm{n}=34)$ and tax issues $(34.2 \%, \mathrm{n}=25)$. The latter focused on the budget issues of the PPACA legislation. A tax on higher income individuals and families was discussed as a possible budget source, suggesting that certain individuals would assume a heavy financial burden with the passage of the PPACA.

The news networks' coverage was systematically lacking in information and depth. Even when information was supplied, the stories ignored it and superficially covered the health care reform by polarizing supporters against non-supporters and ignoring the specific contents of the PPACA. Apart from the government option, details about the PPACA such as eligibility, benefits, insurance requirements, and prescription drugs were less frequently covered in the stories. Preventative care was not discussed at all, although there is a substantial part of the PPACA which provides for Mammograms and other preventive 
healthcare. Ironically, the government option was the most frequently discussed frame regarding the contents of PPACA but was not included in the final legislation (Table 2).

The PPACA was most frequently covered in August 2009, one month before the President first presented his vision of the legislation. Without concrete details provided by the White House, journalists often speculated on the proposed contents of the bill, which resulted in inaccuracy in news contents. Numerous stories $(n=33)$ discussed the possibility of and possible provisions of a government run health care plan, however, the final legislation did not contain the government option (US Government, 2019) (Table 2).

The overall tone of the news stories was found to be neutral (Table 3; 83.56\%, $\mathrm{n}=61$ ). However, an examination of the news tone by network revealed that CBS had a significantly higher number of negatively toned stories, eight of eleven respectively. Indeed, CBS maintained a relatively negative tone in its coverage of the PPACA issues among the three TV networks (Table 3; tone = -.285; $d f=2, F=4.4, p<.05)$.

Their negative perspective is reflected through their language selection. Reporters and anchors often introduced the health care stories by emphasizing the President's struggle to gain support. Comments like, "The President tried to kick-start his health "overhaul" and "his efforts have been slowed by controversy on Capitol Hill-especially by the cost," by CBS reporter Chip Reid (Couric \& Reid, 2009) emphasized cost over benefit. Brian Williams stated, "The President tried again today to be heard," focusing on the partisan conflict (Williams \& O'Donnell, 2009) and on September 9, 2009, NBC's Brian Williams described the President as "bruised along the way..." (Williams \& Todd, 2009). The news stories often had over-the-shoulder graphics at the beginning of each story. These graphics were often the first introduction to the frames which were being presented. CBS's graphics included "Health Care Compromise," "Health Care Consensus," or "Health Care Battle," whereas those of NBC were consistently titled "Health Care Overhaul," which may suggest that CBS framed the reform as a political issue rather than legislation proposed to solve a social issue (Couric, 2008; Couric \& Attkisson, 2009; Curry \& Chuck, 2009; Curry \& Todd, 2009).

Next, we examined which news frames contained negative tones. Out of the 11 negatively toned news stories, stories number eight and six included opposing

Table3. Frequencies of news frames in network news.

\begin{tabular}{ccccc}
\hline & Negative & Neutral & Positive & Overall Tone (range from -1 and 1$)$ \\
\hline $\mathrm{ABC}(\mathrm{N}=3)$ & 0 & 3 & 0 & 0 \\
$\mathrm{NBC}(\mathrm{N}=42)$ & 3 & 38 & 1 & $-.048^{*}$ \\
$\mathrm{CBS}(\mathrm{N}=28)$ & 8 & 20 & 0 & $-.285^{\star}$ \\
Total $(\mathrm{N}=73)$ & 11 & 61 & 1 & -.137 \\
\hline
\end{tabular}

Note: chi-square test $(\mathrm{df}=4, p=.078)=8.387$; negative, neutral and positive tones were coded as $-1,0$ and 1 , respectively. Mean difference between NBC and CBS is .263 ( $\mathrm{df}=2, \mathrm{~F}=4.4, p=.016<.05)$. 
and supporting opinions of citizens, respectively. Financing, tax, government option and the death panel issue also were framed three times in the negative toned stories. Benefits of the PPACA, prescription drug, and Medicaid were framed twice negatively. Overall, the conflict frames and concerns of the cost of the health care reform-such as financing and tax burden-projected negative perspectives of the PPACA. Death panel also was one frame that conveyed a negative viewpoint to the audience, although it was not accurate information regarding the PPACA.

\section{Comparing News Releases to News Stories: RQ 3}

Lastly, we compared the representations of news releases with network news coverage (RQ3). The analysis revealed discrepancies in framing between the news coverage and news releases. For example, TV news pointed out taxes as the main source of the reform budget (33.2\% of network news frames), where as news releases pointed to enhancing Medicare efficiency as the primary contributor to the financing of the PPACA (53.8\% of news releases frames). The White House also, in contrast to the news stories, suggested that the need for health care reform was a priority compared to the cost (46.2\% of the news releases). Television news, however, de-emphasized the issues facing the current health care system, emphasizing instead the cost of healthcare reform $(46.6 \%$ of the news) (Figure 1).

As committees met, and drafts of legislation were presented to both the House of Representatives and the Senate, several consistent threads emerged among the stories. TV news stories focused on the controversial government option (45.2\%, $\mathrm{n}=33$ ), where as the White House news releases highlighted eligibility as the most critical aspect of the PPACA $(52.8 \%, \mathrm{n}=7)$. As would be expected, the news releases highlighted supporting opinions from citizens and politicians $(46.2 \%, \mathrm{n}=6)$, while the TV stories focused on the polarization of opinions about the PPACA (58.9\% of opposing and $49.3 \%$ of supporting opinion). Certain controversial issues were emphasized in this conflict.

Several stories from both networks detailed heavily populated, out-of control town hall meetings in which participants were yelling at the speakers. A CBS

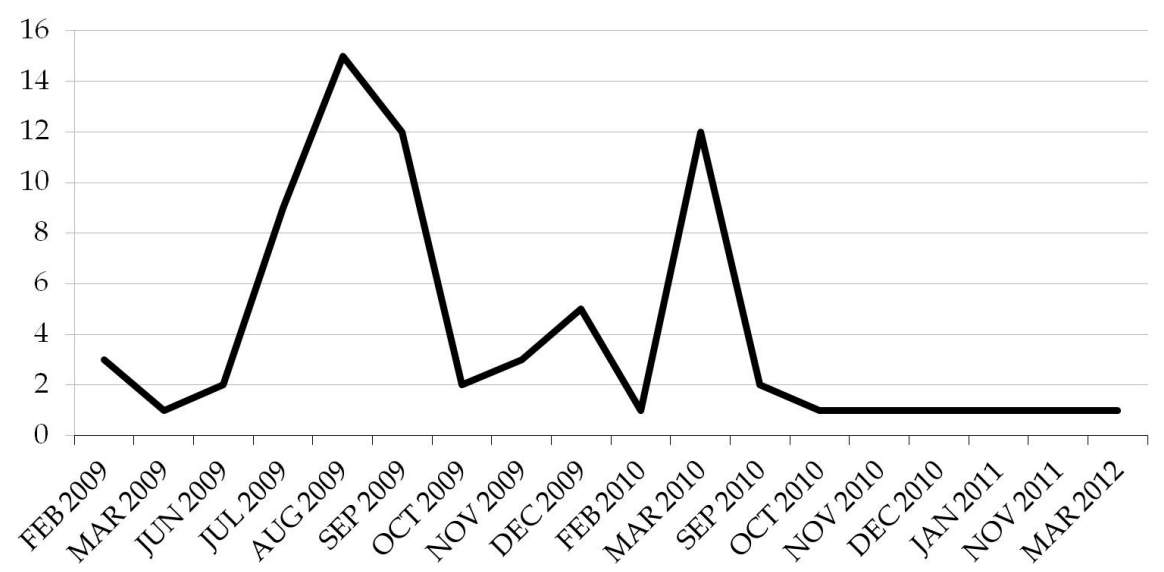

Figure 1. Frequency of TV news coverage on PPACA by time line (2009-2012). 
story broadcast on August 7, 2009 showed angry crowds and described how one woman was escorted from the meeting by police (Reid, 2009). On September 10, 2009, NBC and CBS covered an outburst by Representative Joe Wilson (R-SC) on the floor of the House of Representatives in which Wilson called the President a liar during the President's address to congress about health care reform. This story continued in the media for days afterwards with the networks repeatedly showing the outburst and then subsequent interviews with Obama and Wilson (Reid \& Couric, 2009; Todd \& Williams, 2009).

Although not as frequent a frame, the public's fear of "death panels" was a myth that TV stories drew attention to $(12.3 \%, \mathrm{n}=9)$, despite a lack of evidence of that in the legislation. However, none of the news releases responded or clarified the issue $(n=0)$. Preventative care occupied a critical part of the PPACA legislation, committing an entire section of the bill (Title IV) to the prevention of chronic diseases and improving public health (US Government, 2019). News releases discussed preventative care $(n=3,23.1 \%)$, however the television news stories ignored it $(\mathrm{n}=0)$.

\section{Conclusions \& Discussion}

The results of this study's content analysis show a perfect storm between deficient news releases distributed by the White House and the narrow angles journalists chose to represent the PPACA. How the issue was framed, and how much information was provided, has implications for how the audience may have perceived the PPACA. According to Rivers and Schramm (Rivers \& Schramm, 1969: p. 27), the consistent power of the mass media should be thought of, "not as a tidal wave, but as a great river".

These results provide evidence that the burden of providing detail about the healthcare legislation itself should not be completely born by the journalists. Although the coverage of the PPACA begins in January of 2009, the President's inaugural year, the first draft of the legislation by the House of Representatives is not unveiled until October 29, 2009; approximately ten months after the White House announced the campaign to reform healthcare. As journalists scrambled to cover the PPACA, they were given little help from the White House in clarifying how the legislation would impact viewers.

The literature suggests that while the media are not the only influence upon public opinion, the framing of issues in specific ways does indeed impact public opinion (Goffman, 1974; Porto, 2007; Scheufele, 1999; Semetko \& Valkenburg, 2000). The results of this analysis indicated that the networks devoted what seemed to be an adequate amount of coverage in their evening newscasts (with the exception of $\mathrm{ABC}$ ) to the PPACA. However, the findings also indicated that the stories generally focused on peripheral aspects of health care reform, leaving viewers in the dark about the concrete contents of the legislation and how it would affect them as individuals. These stories often assessed the cost and risk to key stakeholders, partisan conflict over the legislation, and individual's health- 
care stories in which the reporters failed to relate the relevance of the story subject matter to the PPACA.

Mass communication scholarship supports the premise that television news may rely on conflict and emotion to make stories interesting to viewers, while ignoring other more critical aspects of a story (Farnsworth \& Lichter, 2011; Gitlin, 1980; Rhode, 1995; Tuchman, 1979). The reliance upon these news values often results in the elimination of more legitimate coverage of a topic in the pursuit of ratings. This study showed a substantial avoidance of concrete contents of the legislation such as preventative healthcare and a reliance upon conflict by all networks.

Comparing the news stories to the news releases, Entman's four functions of framing (define problems, diagnose causes, make moral judgments and suggest remedies) painted vastly different pictures of healthcare reform (Entman, 1993). Prevalent news frames (Entman, 1993) in the news stories and the releases both focused primarily on the first and second functions of framing, defining problems and diagnosing causes, but in different ways. The news releases were much more likely to support reform as a remedy; the fourth function of framing, whereas the news stories did not frame the PPACA as remedy, but as the problem itself. Comparing the news releases to the television news stories, the news releases often emphasized cost savings, defining healthcare reform as the remedy for existing health care system problems, while the news stories defined the problem as reform and not the current system, emphasizing its cost and the financing and defining the problems associated with implementing healthcare reform.

Conflicting frames between the Obama administration and the media served to present the PPACA as a current event and issue but failed to define it in ways discernible to the viewing audience. This lack of definition has implications for the public's understanding of the legislation and as a result, the PPACA remains, as a controversial piece of legislation. While a preponderance of mass communications literature (Farnsworth \& Lichter, 2011; Gitlin, 1980; Kohrs, 1998; Stephens, 1996; Tuchman, 1979) has blamed the media solely for misrepresentation or underrepresentation of issues, we found that the White House was at least partially responsible for the superficiality of coverage of the PPACA.

\section{Limitations and Future Research}

This study makes a significant contribution to the literature by shining a light on the lack of comprehensive information provided by TV news coverage of the PPACA. The evidence suggests that the White House News administration played a role in this lack of coverage by not providing a clear picture of the PPACA. With this information in hand, there are several limitations in this study that future studies should address.

Secondly, we discovered framing discrepancies between news coverage and news releases. Further studies could investigate where journalists obtained information about the details of PPACA in addition to or external to news releases. 
In addition, only 13 news releases were available from the White House between 2009 and 2012. This may be evidence that the government diversified communication channels between the public and journalists. Future study needs to examine how the government utilizes new media channels such as websites like healthcare.gov and social media to inform the public about pending and current policies and legislation.

\section{Conflicts of Interest}

The authors declare no conflicts of interest regarding the publication of this paper.

\section{References}

Berry, J. (2009). The Effects of Income on Appliances U.S. Households. Washington, DC: Energy Information Administration.

CDC (2012). FASTSTATS: Health Insurance Coverage. http://www.cdc.gov/nchs/fastats/hinsure.htm

Claes, H. (2012). New Avenues for Framing Research. American Behavioral Scientist, 56, 365-375.

Cortes, N. (Director) (2009). Health Care Reform. Washington, DC: CBS. [Video/DVD]

Couric, K. (Director) (2008). New Hampshire Interview with McCain. USA. [Motion Picture]

Couric, K., \& Attkisson, S. (Directors) (2009). Health Care Compromise: "Back Room Deal". Washington DC: Capital Broadcasting Systems. [Video/DVD]

Couric, K., \& Reid, C. (Directors) (2009). Obama/News Conference. Washington, DC: CBS. [Video/DVD]

Culbert, D. (1998). Television's Visual Impact on Decision-Making in the USA, 1968: The Tet Offensive and Chicago's Democratic National Convention. Journal of Contemporary History, 33, 419-449.

Curkan-Flanagan, M. (2000). The Contemporary Militia: Network News Framing of a Social Movement. Unpublished Doctoral Dissertation, Knoxville, TN: University of Tennessee.

Curry, A., \& Chuck, T. (Directors) (2009). Health Care Overhaul. Washington DC: National Broadcasting Company. [Video/DVD]

Curry, A., \& Todd, C. (Directors) (2009). Health Care Overhaul: Public Option. Washington DC: National Broadcasting Company. [Video/DVD]

Dan, B. B. (1992). TV or Not TV Communicating Health Information to the Public. Journal of the American Medical Association, 268, 1026-1027. https://doi.org/10.1001/jama.1992.03490080100034

Dorfman, L., Schauffler, H., Wilkerson, J., \& Feinson, J. (1996). Local Television News Coverage of President Clinton's Introduction of the Health Security Act. Journal of the American Medical Association, 275, 1201-1204. https://doi.org/10.1001/jama.1996.03530390067038

Dutta-Burgman, M. J. (2005). Operation Iraqi Freedom: Mediated Public Sphere as a Public Relations Tool. Atlantic Journal of Communication, 13, 220-241. https://doi.org/10.1207/s15456889ajc1304_2

Edy, J. (1999). Journalistic Uses of Collective Memory. Journal of Communication, 49, 71-85. https://doi.org/10.1111/j.1460-2466.1999.tb02794.x 
Entman, R. M. (1993). Framing: Towards Clarification of a Fractured Paradigm. Journal of Communication, 43, 51-58. https://doi.org/10.1111/j.1460-2466.1993.tb01304.x

Farnsworth, S. J., \& Lichter, S. R. (2004). Increasing Candidate-Centered Televised Discourse. The Harvard International Journal of News/Politics, 9, 76-93. https://doi.org/10.1177/1081180X03262510

Farnsworth, S. J., \& Lichter, S. R. (2011). The Nightly News Nightmare. New York: Rowman \& Littlefield.

Gamson, W. A., \& Modigliani, A. (1989). Media Discourse and Public Opinion on Nuclear Power: A Constructionist Approach. American Journal of Sociology, 95, 1-37. https://doi.org/10.1086/229213

Gans, H. J. (1980). Deciding What's News: A Study of CBS Evening News, NBC Nightly News, Newsweek and Time. New York: Vintage Books.

Gitlin, T. (1980). The Whole World Is Watching: Mass Media in the Making. Los Angeles, CA: University of California News.

Goffman, E. (1974). Frame Analysis: An Essay on the Organization of Experience. New York: Harper \& Row.

Ha-Ilan, N. (2001). Images of History in Israel Television News: The Territorial Dimensions of Collective Memories, 1987-1990. In G. Edgerton, \& P. Rollins (Eds.), Television Histories: Shaping Collective Memory in the Media (pp. 207-228). Lexington, KY: University of Kentucky News.

Hallin, D. C. (1984). The Media, the War in Vietnam, and Political Support: A Critique of the Thesis of an Oppositional Media. The Journal of Politics, 46, 2-24. https://doi.org/10.2307/2130432

Hansen, K. A., \& Ward, J. (1994). Local Breaking News: Sources, Technology, and News Routines. Journalism Quarterly, 71, 561-572. https://doi.org/10.1177/107769909407100308

Kane, J. (2012). Health Care Costs: How the U.S. Compares with Other Countries. The Rundown: PBS.

Kohrs, C. K. (1998). The Discursive Performance of Femininity: Hating Hillary. Rhetoric \& Public Affairs, 1, 1-19. https://doi.org/10.1353/rap.2010.0172

Lichter, S. R., \& Noyes, N. E. (1995). Good Intentions Make Bad News. Lanham, MD: Rowan \& Littlefield.

McQuail, D. (2005). McQuail's Mass Communication Theory. Thousand Oaks, CA: Sage.

Morris, J. S., \& Forgette, R. (2007). News Grazers, Television News, Political Knowledge, and Engagement. The Harvard International Journal of News/Politics, 12, 91-107. https://doi.org/10.1177/1081180X06297122

Peters, E., McCaul, K. D., Stefanek, M., \& Nelson, W. (2006). A Heuristics Approach to Understanding Cancer Risk Perception: Contributions from Judgment and Decision-Making Research. Annals of Behavioral Medicine, 31, 45-52. https://doi.org/10.1207/s15324796abm3101_8

Porto, M. P. (2007). Framing Controversies: Television and the 2002 Presidential Election in Brazil. Political Communication, 24, 19-36. https://doi.org/10.1080/10584600601128705

Purcell, K., Rainie, L., Mitchell, A., Rosenstiel, T., \& Olmstead, K. (2010). Understanding the Participatory News Consumer. Washington DC: Pew Internet Project.

Reid, C. (2009). Health Care Reform/Protests. Green Bay, WI and Hillsborough, MO: CBS. 
Reid, C., \& Couric, K. (2009). Health Care Reform/Obama Address/Wilson Outburst. Washington DC: CBS.

Rhode, D. L. (1995). Media Images, Feminist Issues. Signs, 20, 685-710. https://doi.org/10.1086/495006

Rivers, W. L., \& Schramm, W. D. (1969). Responsibility in Mass Communication. New York: Harper and Rowe.

Rodman, G., \& Adler, R. (2002). Understanding Human Communication. New York: Oxford University Press.

Scheufele, D. A. (1999). Framing as a Theory of Media Effects. Journal of Communication, 49, 103-122. https://doi.org/10.1111/j.1460-2466.1999.tb02784.x

Semetko, H., \& Valkenburg, P. (2000). Framing European Politics: A Content Analysis of News and Television News. Journal of Communication, 50, 93-109. https://doi.org/10.1111/j.1460-2466.2000.tb02843.x

Slovic, P. (1995). The Construction of Preference. American Psychologist, 50, 364-371. https://doi.org/10.1037/0003-066X.50.5.364

Sonderman, J. (2012). Survey: Americans Turn to Established Media for Breaking News. St. Petersburg, FL: Poynter Institute.

Stephens, M. (1996). On Shrinking Sound Bites. Columbia Journalism Review, 35, 22. http://search.proquest.com.jproxy.lib.ecu.edu/docview/230344859? accountid=10639

Strauss, A., \& Corbin, J. (1998). Basics of Qualitative Research: Techniques and Procedures for Developing Grounded Theory. Thousand Oaks, CA: Sage Publications.

Terkildsen, N., \& Schnell, F. (1997). How Media Frames Move Public Opinion: An Analysis of the Women's Movement. Political Research Quarterly, 50, 879-900. https://doi.org/10.1177/106591299705000408

Todd, C., \& Williams, B. (2009). Health Care Reform/Obama Address/Wilson. Washington DC: NBC.

Tuchman, G. (1978). Television News and the Metaphor of Myth. Studies in the Anthropology of Visual Communication, 5, 56-62. https://doi.org/10.1525/var.1978.5.1.56

Tuchman, G. (1979). Women's Depiction by the Mass Media. Signs, 4, 528-542. https://doi.org/10.1086/493636

Tuggle, C. A., Carr, F., \& Huffman, S. (2007). Broadcast News Handbook. Boston: McGraw Hill.

US Government (2019). Patient Protection and Affordable Care Act. https://www.healthcare.gov/glossary/patient-protection-and-affordable-care-act/

Wallack, L., \& Dorfman, L. (1992). Television News, Hegemony, and Health. American Journal of Public Health, 82, 2. https://doi.org/10.2105/AJPH.82.1.125-a

Williams, B., \& O’Donnell, K. (2009). Health Care Reform/Obama Interview. Washington DC: NBC.

Williams, B., \& Todd, C. (2009). Health Care Reform/Obama Address. Washington DC: NBC. 